\title{
Molecular biological evidence for the occurrence of uncultured members of the actinomycete line of descent in different environments and geographical locations
}

\author{
Holger Rheims, Cathrin Spröer, Fred A. Rainey and Erko Stackebrandt
}

Author for correspondence: Erko Stackebrandt. Tel: +495312616 352. Fax: +495312616 418.
e-mail: erko@gbf-braunschweig.de

DSMZ-Deutsche Sammlung von Mikroorganismen und Zellkulturen $\mathrm{GmbH}$,

Mascheroder Weg 1b, 38124

Braunschweig, Germany

\begin{abstract}
A 165 rDNA based molecular ecological study was performed on a sample taken from a peat bog in Germany. Total DNA was extracted by directly lysing micro-organisms in the peat matrix. The $5^{\prime} 1400$ nucleotides of the bacterial 165 rDNA were amplified using conserved bacterial PCR primers. A clone library was generated by blunt-end cloning and 262165 rDNA clones were analysed. Of these, 37 were located in the Gram-positive phylum, as determined by hybridization to an oligonucleotide probe specific for Grampositive bacteria. Analysis of 17 of these clones by sequence analysis and their comparison with published sequences representing all of the main bacterial phyla indicated their membership of the actinomycete line of descent. These peat clones were found to represent three novel lineages, two of which appear to be related to the species Acidimicrobium ferrooxidans, and 'Candidatus Microthrix parvicella'. Clone sequences of the third group are phylogenetically related to Rubrobacter radiotolerans. Comparison with short 165 rDNA clone sequences obtained from DNA isolated from a geothermally heated soil in New Zealand, and from DNA isolated from soil in Australia, Japan and Finland and marine environments from the Atlantic and the Pacific Oceans, suggests that members of these three groups occur in very different environments across the world.
\end{abstract}

Keywords: $16 \mathrm{~S}$ rDNA clone library, peat, bacterial diversity, actinomycete line of descent

\section{INTRODUCTION}

Recent analysis of $16 \mathrm{~S}$ rDNA clone libraries generated from DNA isolated from terrestrial and marine environments indicated the existence of a broad monophyletic group of hitherto uncultured organisms falling within the actinomycete line of descent. Several such $16 \mathrm{~S}$ rDNA clone sequences, abbreviated MC, were obtained from an Australian forested soil taken from the Mount Coot-tha region in Queensland (Liesack \& Stackebrandt, 1992a, b; Stackebrandt et al., 1993). These $16 \mathrm{~S}$ rDNA clone sequences showed $>83 \%$ similarity to partial sequences from $16 \mathrm{~S}$ rDNA clone libraries from a geothermally

Abbreviation: PVPP, polyvinylpolypyrrolidone.

The EMBL accession numbers for the sequences reported in this paper are X92694-X92710 for the peat bog sequences, X93010 and X93011 for the clones from New Zealand, and $X 98372$ for Rubrobacter radiotolerans. heated soil from New Zealand (abbreviated NZ) (Rainey et al., 1993) and a soil sample from Finland (Saano $e t$ al., 1995). In addition, short $16 \mathrm{~S} \mathrm{rDNA}$ clone sequences from a paddy field (abbreviated PAD) (Maidak et al., 1994), a soybean field (abbreviated FIE) (Ueda et al., 1995) and from marine environments (Fuhrman et al., 1993) showed significant sequence similarities to clone NZ150 (78-94\% partial sequence similarity) and can therefore also be considered members of the MC/NZ $16 \mathrm{~S}$ rDNA clone sequence cluster.

None of these clone sequences are identical or even highly similar to those of described species. At a lower level of relatedness, this group of environmental sequences appears to be a neighbouring group of the two cultured organisms Acidimicrobium ferrooxidans strain TH3 (Clark \& Norris, 1996; Lane et al., 1992) and 'Candidatus Microthrix parvicella' (Blackall et al., 1994, 1996), which display a moderate degree of $16 \mathrm{~S}$ rDNA similarity $(87 \%)$ 
to one another. The latter two organisms form two remotely related lineages that branch deeply in the actinomycete line of descent. Acidimicrobium ferrooxidans (formerly known as strain TH3) was isolated from a mine dump in New Mexico (Brierley, 1978). It is capable of oxidizing ferrous iron at $50{ }^{\circ} \mathrm{C}$, but does not grow at $60{ }^{\circ} \mathrm{C}$. It requires yeast extract and can use either ferrous iron or pyrite as a source of energy. The autotrophic growth of this strain has recently been confirmed (Clark \& Norris, 1996). It decreases the $\mathrm{pH}$ of the growth medium from $2 \cdot 4$ to 1.9 during $4 \mathrm{~d}$ incubation at $50^{\circ} \mathrm{C}$ on a pyrite/yeast extract medium, which indicates sulfide oxidation. 'Candidatus Microthrix parvicella', found in activated sludge sewage treatment plants (Blackall $e t$ al., 1994), has Candidatus status because of its failure to survive long enough in pure culture to enable determination of the phenotypic properties required for its valid description.

The few common phenotypic data that are available for the two species, such as positive Gram-staining behaviour, formation of filaments and requirement for reduced sulphur compounds for growth on artificial media (Blackall et al., 1994, 1996; Clark \& Norris, 1996), are not sufficient to support the apparent phylogenetic relationship of these organisms to one another (Blackall et al., 1994). Consequently, no conclusions can be drawn as to the phenotypic properties of the related $\mathrm{MC} / \mathrm{NZ}$ clone cluster sequences, of which no more than the partial $16 \mathrm{~S}$ rDNA sequence is known.

Recently a peat bog sample from Northern Germany was the subject of an extensive isolation study (von Wintzingerode, 1994). The majority of isolates obtained in the study were Gram-positive bacteria identified as members of the genus Bacillus. Additional isolates were found to be members of the class Proteobacteria and the order Actinomycetales. In this communication we present evidence that $16 \mathrm{~S}$ rDNA sequences similar to those obtained from soil in Australia, Finland, Japan and New Zealand, and from the marine environment, are also found in the low-pH peat bog sample studied by von Wintzingerode (1994). It can thus be speculated that these as yet uncultured organisms are widely distributed in terrestrial and probably in marine samples, where they may contribute to ecologically important processes.

\section{METHODS}

Sampling site. A core drill was used to take samples in April 1994 from a peat bog (depth $40 \mathrm{~cm}$ ) near Gifhorn, Lower Saxony, Germany $\left(10^{\circ} 33^{\prime} \mathrm{E}, 52^{\circ} 30^{\prime} \mathrm{N}\right)$. The drill was driven horizontally into the wall of a drainage channel for $50 \mathrm{~cm}$. The ends of the peat core were discarded. All instruments were autoclaved or rinsed with ethanol and flamed before use. The peat material was immediately placed in dry ice until storage at $-70^{\circ} \mathrm{C}$.

DNA extraction and purification. Genomic DNA was extracted by using a modified direct lysis technique (Ogram et al., 1987). Twenty millilitres of saline/EDTA buffer $(0 \cdot 15 \mathrm{M} \mathrm{NaCl}$, $0 \cdot 01 \mathrm{M}$ EDTA disodium salt, $\mathrm{pH} 8 \cdot 0$ ) were added to $5 \mathrm{~g}$ of a thawed peat sample. Following the addition of $2 \mathrm{~g}$ PVPP (Sigma), prepared as described by Holben et al. (1988), and $150 \mathrm{mg}$ lysozyme (Boehringer), dissolved in $5 \mathrm{ml}$ saline/EDTA buffer, the suspension was mixed and then homogenized with an Ultra-Turrax (Janke \& Kunkel) for $45 \mathrm{~s}$. After incubation at $37^{\circ} \mathrm{C}$ for $30 \mathrm{~min}, 200 \mu \mathrm{l}$ proteinase $\mathrm{K}(1 \%$, w/v ; Boehringer $)$ and $500 \mu \mathrm{l}$ SDS $(25 \%, \mathrm{w} / \mathrm{v})$ were added, homogenized by shaking and the homogenate was further incubated at $70^{\circ} \mathrm{C}$ for $45 \mathrm{~min}$. Soil debris and PVPP were pelleted by centrifugation at $5800 \mathrm{~g}$ for $20 \mathrm{~min}$. The supernatant was transferred to a fresh tube and subsequently extracted with an equal volume of tris/EDTA-saturated phenol, phenol/chloroform $(1: 1, \mathrm{v}: \mathrm{v})$ and chloroform, each step followed by centrifugation as indicated above. Following the final extraction step, nucleic acids were precipitated for $18 \mathrm{~h}$ at $-18^{\circ} \mathrm{C}$ by addition of $0 \cdot 1$ vol. $3 \mathrm{M}$ sodium acetate ( $\mathrm{pH} 5.2$ ) and 2 vols absolute ethanol. After centrifugation for $30 \mathrm{~min}$ at $18000 \mathrm{~g}$, the supernatant was discarded and the pellet washed twice with $10 \mathrm{ml} 70 \%(\mathrm{v} / \mathrm{v})$ ethanol, with centrifugation steps as before. The DNA pellet was dried in a vacuum centrifuge and dissolved in $300 \mu \mathrm{l}$ sterile water. Further purification was with the Prep-AGene DNA Purification Kit (Bio-Rad), using $10 \mu \mathrm{l}$ of the DNA binding matrix. After this purification procedure, humic acids could not be detected by electrophoresis of a DNA aliquot on a $1 \%(\mathrm{w} / \mathrm{v})$ agarose gel.

Amplification and cloning of 165 rDNA. This was performed using Ultma DNA polymerase, with the buffer supplied by the manufacturer (Perkin Elmer) and bacterial 16S rDNA oligonucleotide primers $27 \mathrm{f}$ and $1385 \mathrm{r}$ (Table 1). The PCR protocol is a modification of the one recommended by Perkin Elmer for the use of Ultma polymerase, in that $4 \mu \mathrm{l}$ of $25 \mathrm{mM} \mathrm{MgCl}_{2}$ solution was used. PCR was performed on a DNA thermal cycler (model 9600, Perkin Elmer); amplification was for 28 cycles (annealing for $1 \mathrm{~min}$ at $52{ }^{\circ} \mathrm{C}$, elongation for $2 \mathrm{~min}$ at $72{ }^{\circ} \mathrm{C}$, denaturation for $1 \mathrm{~min}$ at $93^{\circ} \mathrm{C}$ ). PCR products were purified with the Prep-A-Gene DNA Purification Kit. Cloning was performed with the pCR-Script $\mathrm{SK}(+)$ Cloning Kit (Stratagene) and Epicurian Coli XL1-BLUE MRF'KAN competent cells (Stratagene). Modifications of the protocol given in the Stratagene instruction manual included incubation of the ligation mix for at least $2 \mathrm{~h}$ and heat pulsing of the competent cells for $50 \mathrm{~s}$ at $42^{\circ} \mathrm{C}$.

Recombinant plasmids were extracted by boiling an inoculation loopful of the bacterial cells in $100 \mu \mathrm{l}$ water $\left(10 \mathrm{~min}\right.$ at $\left.98^{\circ} \mathrm{C}\right)$ and pelleting the debris by centrifugation $(1 \mathrm{~min}$ at $15000 \mathrm{~g}$ ). The supernatant was transferred into fresh tubes. The inserts were further amplified using Taq polymerase (Boehringer) and M13 (-20) and M13rev primers (Table 1) in a reaction volume of $50 \mu 1$, and with the PCR cycles as indicated above.

Determination of nucleotide sequences. Sequencing reactions of the $16 \mathrm{~S}$ rDNA fragments were performed with the Taq DyeDeoxy Terminator Cycle Sequencing Kit (Applied Biosystems) and electrophoresed using an automated sequence analyser (model 373A; Applied Biosystems). The length of the analysed stretches of the 17 clones ranged from 1329 to 1373 nucleotides. A shorter stretch comprising about 400 nucleotides was analysed in an additional 20 clones.

Phylogenetic analysis. The sequencing data files were manually aligned with ESEE (the Eyeball Sequence Editor) (Cabot \& Beckenbach, 1989) and then included in the alignment editor ae2 (Maidak et al., 1994). The presence of possible chimeric structures was investigated using the CHECK_CHIMERA program (Maidak et al., 1994). The 16S rDNA clone sequences were compared to sequences representing major lines of descent. Similarity values were transformed into phylogenetic distance values that compensate for multiple substitutions at any given site in the sequence (Jukes \& Cantor, 1969). The least-squares distance method of DeSoete (1983) as well as the neighbourjoining method contained in the PHYLIP package (Felsenstein, 
Table 1. Sequences of oligonucleotide primers and probes used

\begin{tabular}{|lll|}
\hline Primer/probe & \multicolumn{1}{c|}{ Sequence $\left(\mathbf{5}^{\prime}-\mathbf{3}^{\prime}\right)$} & \multicolumn{1}{c|}{ Reference/source } \\
\hline $27 \mathrm{f}$ & GAG TTT GAT CCT GGC TCA G & Lane (1991) \\
$1385 \mathrm{r}$ & CGG TGT GT(A/G) CAA GGC CC & Stackebrandt \& Liesack (1993) \\
$519 \mathrm{r}$ & G(T/A)A TTA CCG CGG C(T/G)G CTG & Stackebrandt \& Liesack (1993) \\
M13(-20) & GTA AAA CGA CGG CCA GT & Stratagene (1994) \\
M13rev & GGA AAC AGC TAT GAC CAT G & Stratagene (1994) \\
Gram-positive & TCA TCA TGC CCC TTA TG & This work \\
mycoides & TAA TAT TTT GAA CTG CAT AG & von Wintzingerode (1994) \\
TH3 & CAG CTC GCT GGG ACG & This work \\
\hline
\end{tabular}

1993) were used in the construction of phylogenetic dendrograms. For calculation of bootstrap values, 100 trees were analysed using the programs NJFIND and NJвоOT.

DNA blotting and hybridization with oligonucleotide probes. The PCR products of the $16 \mathrm{~S}$ rDNA inserts were purified with the Prep-A-Gene DNA purification kit and eluted in $50 \mu \mathrm{l}$ water. Three microlitre samples of each of the $16 \mathrm{~S}$ rDNA PCR products were then denatured and applied to a nylon membrane (Hybond N, Amersham), using a dot-blot apparatus (Bio-Rad) and fixed by UV $(260 \mathrm{~nm})$ for $100 \mathrm{~s}$. Hybridization and detection were performed according to the manufacturer's instructions using the DIG Luminescent Detection Kit (Boehringer). Oligonucleotide probes were synthesized by the Pharmacia Biotech Oligo-Synthesis-Service (Pharmacia) and labelled using the DIG Oligonucleotide $3^{\prime}$-End labelling kit (Boehringer). The 16S rDNA PCR products of the controls and the peat clones were fixed onto a total of three membranes. All three membranes were processed simultaneously in the same roller tube to ensure reproducible hybridization and detection conditions. Hybridization was carried out at room temperature for $4 \mathrm{~h}$. The temperature of the stringency wash in $6 \times \mathrm{SSC}, 0 \cdot 1 \%$ SDS buffer was $37^{\circ} \mathrm{C}$. Even after washing at more stringent temperatures, unspecific binding was not observed. Exposure to an X-ray film (Fuji 51209) was for $2 \mathrm{~h}$.

\section{RESULTS}

\section{Isolation of DNA}

Comparison of the isolated DNA by agarose gel electrophoresis with and without treatment with PVPP showed a significant difference in the amount of humic acids present in the extracts. Without PVPP treatment, humic acids appeared under UV light as a bright band migrating faster than DNA in the agarose gel. Using DNA prepared without PVPP treatment as PCR template resulted in no $16 \mathrm{~S}$ rDNA PCR product being obtained. As judged from the UV-visualized gel, the amount of humic acids was significantly reduced by PVPP treatment. When used as a PCR template, DNA which had been PVPP treated and Prep-A-Gene purified gave a $16 \mathrm{~S}$ rDNA amplification product.

\section{Analysis of the clone library}

The generated $16 \mathrm{~S}$ rDNA clone library comprised a total of 262 clones, designated TM (for 'Torf, mittlere Schicht' $=$ peat, middle layer). The reamplified PCR products of the $16 \mathrm{~S}$ rDNA clone inserts, together with reference $16 \mathrm{~S}$ rDNA PCR products of 26 strains of known phylogenetic affiliation, were blotted onto a membrane filter. The reference $16 \mathrm{~S}$ rDNA represented 13 different bacterial genera, seven isolates from the same peat sample (von Wintzingerode, 1994) and two plant chloroplasts (Table 2). In order to check the availability of target DNA for oligonucleotide probing, the filters were hybridized with a universal bacterial oligonucleotide probe (519r, see Table 1). The reference $16 \mathrm{~S}$ rDNAs and all but three of the 262 peat clones gave positive signals when hybridized with this probe (data not shown).

As a previous analysis of cultured strains isolated from the same location indicated the presence of mainly Grampositive bacteria (von Wintzingerode, 1994), their presence in the clone library was checked with a probe designed to specifically detect $16 \mathrm{~S}$ rDNA of Grampositive bacteria (Gram-positive, Table 1). This probe hybridized with all of the Gram-positive control rDNAs and with 37 of the $16 \mathrm{~S}$ rDNA clones $(15 \%$ of the total) (Fig. 1). In contrast to the isolation study, which indicated the presence of a substantial number of Bacillus mycoides strains in the peat sample, 16S rDNA of this taxon was not present in the clone library as indicated by the absence of signals with a $B$. mycoides-specific oligonucleotide probe (mycoides, Table 1). As only the DNAs of the Bacillus reference strains (listed in Table 2 ) gave a positive signal under the conditions used with this probe, it was concluded that clones originating from $B$. mycoides were absent in the $26216 \mathrm{~S}$ rDNA clones investigated.

Further phylogenetic analyses concentrated on sequence comparison of 26 randomly selected $16 \mathrm{~S}$ rDNA clones which had hybridized with the Gram-positive probe. The CHECK_CHIMERA analysis (Maidak et al., 1994) of 17 almost complete sequences indicated that none of them were chimeric structures. Phylogenetic analysis of these 17 sequences, based on the comparison of stretches of 1329 to 1373 nucleotides, revealed the presence of three groups I-III, see Fig. 2), of which groups II and III were more closely related (88-91\% 16S rDNA sequence similarity) to each other than either was to clone sequences of group I (82-86\% 16S rDNA sequence similarity). For groups I and III the intragroup relatedness was $>94 \%$, while within group II the relatedness was $>92 \%$. 16S rDNA sequences of clones from group I could be distinguished 
Table 2. 165 rDNA PCR products used for dot-blot hybridization with different oligonucleotide probes

\begin{tabular}{|c|c|c|}
\hline $\begin{array}{l}\text { Position on } \\
\text { membrane* }\end{array}$ & Designation/identity & Source/strain $\dagger$ \\
\hline A1 & Bacillus cereus & $\operatorname{DSM} 31^{\mathrm{T}}$ \\
\hline $\mathrm{A} 2$ & Bacillus mycoides & DSM 307 \\
\hline A3 & Bacillus mycoides & DSM $2048^{\mathrm{T}}$ \\
\hline A4 & Bacillus thuringiensis & DSM $2046^{\mathrm{T}}$ \\
\hline A5 & Bacillus subtilis & DSM $10^{\mathrm{T}}$ \\
\hline A6 & Isolate $1 \mathrm{~F} 8 \mathrm{o} 2 \ddagger$ & $99 \cdot 5 \%$ Bacillus mycoides $\$$ \\
\hline A7 & Isolate $3 \mathrm{Gym} 7 \ddagger$ & $96 \%$ Methylobacterium fujisawaense \\
\hline A8 & Isolate 3SCo6 & $100 \%$ Streptomyces murinus $\$$ \\
\hline A9 & Isolate $2 \mathrm{Miu} 8 \ddagger$ & $99.2 \%$ Mycobacterium diernboferi $\$$ \\
\hline A10 & Isolate $2 \mathrm{Gyu} 7 \ddagger$ & $98.3 \%$ Mycobacterium sphagnum $₫$ \\
\hline A11 & Isolate $2 \mathrm{Gyo} 9 \ddagger$ & $97 \cdot 8 \%$ Bacillus circulans $\$$ \\
\hline A12 & Isolate $3 \mathrm{Mio} 8 \ddagger$ & $96 \cdot 1 \%$ Paenibacillus polymyxa $\$$ \\
\hline B1 & Comamonas acidovorans & DSM $39^{\mathrm{T}}$ \\
\hline $\mathrm{B} 2$ & Jantbinobacterium lividum & $\operatorname{DSM} 1522^{\mathrm{T}}$ \\
\hline B3 & Streptomyces albidoflavus & $\mathrm{DSM} 40455^{\mathrm{T}}$ \\
\hline B4 & Metbylobacterium fujisawaense & DSM $5686^{\mathrm{T}}$ \\
\hline B5 & Rhodococcus rbodochrous & $\mathrm{DSM} 43241^{\mathrm{T}}$ \\
\hline B6 & Desulfotomaculum orientis & $\operatorname{DSM} 765^{\mathbf{T}}$ \\
\hline B7 & Desulfovibrio africanus & DSM $2603^{\mathrm{T}}$ \\
\hline B8 & Spirochaeta africana & DSM $8902^{\mathrm{T}}$ \\
\hline B9 & Artbrobacter globiformis & DSM $20124^{\mathrm{T}}$ \\
\hline $\mathrm{B} 10$ & Escherichia coli & DSM 498 \\
\hline B11 & Planctomyces limnophilus & DSM $3776^{\mathrm{T}}$ \\
\hline B12 & Gemmata obscuriglobus & $\operatorname{DSM} 5831^{\mathrm{T}}$ \\
\hline $\mathrm{C} 1$ & Equisetum giganteum & DSM PC 592 \\
\hline $\mathrm{C} 2$ & Marchantia polymorpha & DSM PC 713 \\
\hline
\end{tabular}

* The letter and the number indicate the row and column on the membrane, blot I in Fig. 1.

$\dagger \mathrm{T}$, type strain.

$\ddagger$ Strain designation of isolates obtained from $\mathrm{F}$. von Wintzingerode.

$\int$ Values indicate $16 \mathrm{~S}$ rDNA similarity values between the isolate and the closest phylogenetic neighbour, based on partial sequence comparison (von Wintzingerode, 1994).

from those of groups II and III by a short hairpin loop present in the secondary structure from nucleotide positions 198-219 (Escherichia coli nomenclature). Comparison of the analysed Gram-positive TM $16 \mathrm{~S}$ rDNA clone sequences and $16 \mathrm{~S}$ rDNA/RNA reference sequences revealed that all of the TM sequences were most closely related to three $16 \mathrm{~S}$ rDNA sequences from organisms that are phylogenetic members of the actinomycete subphylum of the Gram-positive bacteria (Embley \& Stackebrandt, 1994), i.e. Rubrobacter radiotolerans (sequence determined in this study), Acidimicrobium ferrooxidans (Clark \& Norris, 1996) and 'Candidatus Microthrix parvicella' (Blackall et al., 1994). The $16 \mathrm{~S}$ rDNA similarity values found between clone sequences of cluster I and Rubrobacter radiotolerans were about $85 \%$, while those of groups II and III ranged between 84 and $91 \%$ to $A$. ferrooxidans and 83 and $89 \%$ to 'Candidatus M. parvicella'.

In order to determine whether any of the re-amplified TM clone inserts hybridized with a probe originally designed to detect $A$. ferrooxidans strain $\mathrm{TH} 3$, the filters were hybridized with the TH3 probe (Table 1). As neither strain TH3, nor its DNA, was available to us, a $16 \mathrm{~S}$ rDNA product of this strain could not be included in the hybridization experiments as a positive control. The probe gave positive signals with five clones, of which four were subsequently sequenced (TM36, TM146/TM160, TM220). As revealed by $16 \mathrm{~S}$ rDNA sequence analysis, the four clone sequences were found to be members of clone group I. Apparently, the 15-mer oligonucleotide probe $T H 3$, as originally designed, is not exclusively specific to strain TH3.

The results of phylogenetic analysis using two different distance methods and the Maximum Likelihood method gave identical branching patterns; differences were only found in the length of the branches. A tree based on the distance method of DeSoete (1983) is shown in Fig. 2, in which the 16S rDNA sequences of Bacillus subtilis as well as Acidobacterium capsulatum (Kishimoto et al., 1991; Hiraishi et al., 1995) and several related clone sequences from Mount Coot-tha soil served as outgroup sequences. 


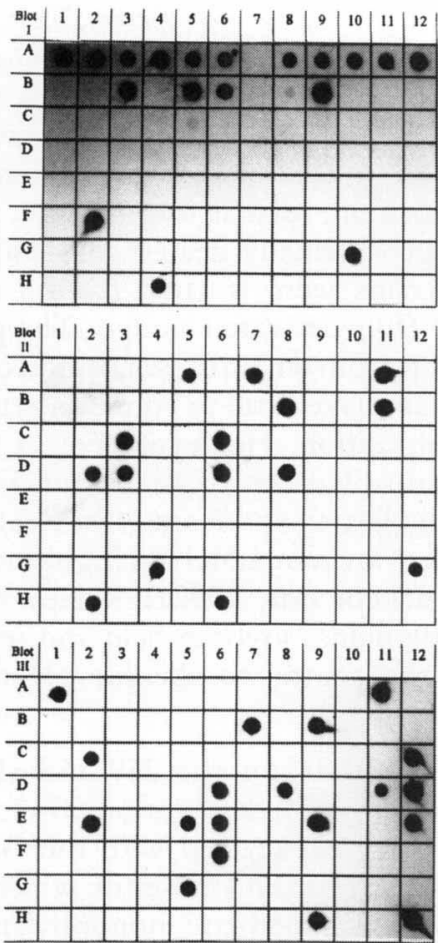

Fig. 1. Hybridization of the TM clones with probe Grampositive. Each membrane (designated Blot I, Blot II and Blot III) carried $9616 \mathrm{~S}$ rDNA PCR products. These are: for Blot I, controls 1 to 26 (see Table 2 for details) from position $A 1$ to $C 2$ and clones TM1 to TM70 from position $\mathrm{C} 3$ to $\mathrm{H} 12$; for Blot II, clones TM71 to TM166 from position A1 to H12; for Blot III, clones TM167 to TM262 from position A1 to H12. Clones showing a positive signal with the probe are: TM36, 56, 62; TM75, 77, 81, $90,93,97,100,108,109,112,114,146,154,156,160$; TM167, $177,185,187,192,202,208,210,213,214,216,219,220,223$, 226, 232, 243, 259, 262.

The latter sequences were included because they were previously found to cluster deeply with Atopobium (Lactobacillus) minutum at the base of the actinomycete line of descent (Stackebrandt et al., 1993). The inclusion of the $16 \mathrm{~S}$ rDNA sequence of Acidobacterium capsulatum (Hiraishi et al., 1995) in the database revealed the affiliation of these MC $16 \mathrm{~S}$ rDNA sequences to this species, which constitutes a novel main line of descent within the domain Bacteria. The three TM 16S rDNA clone groups represent distinct lineages, of which groups II and III appear to represent phylogenetic neighbouring taxa. Although some of the bootstrap values are as high as $70 \%$ the relationships of the TM clones are not supported by statistical analysis.

\section{Comparison with published environmental clone sequences}

Comparison of the $16 \mathrm{~S}$ rDNA sequences of actinomycetes and the TM clone sequences with around 150 environmental clone sequences listed in the Ribosomal Database Project (Maidak et al., 1994) constitutes a problem. Many of these environmental sequences cannot be compared as

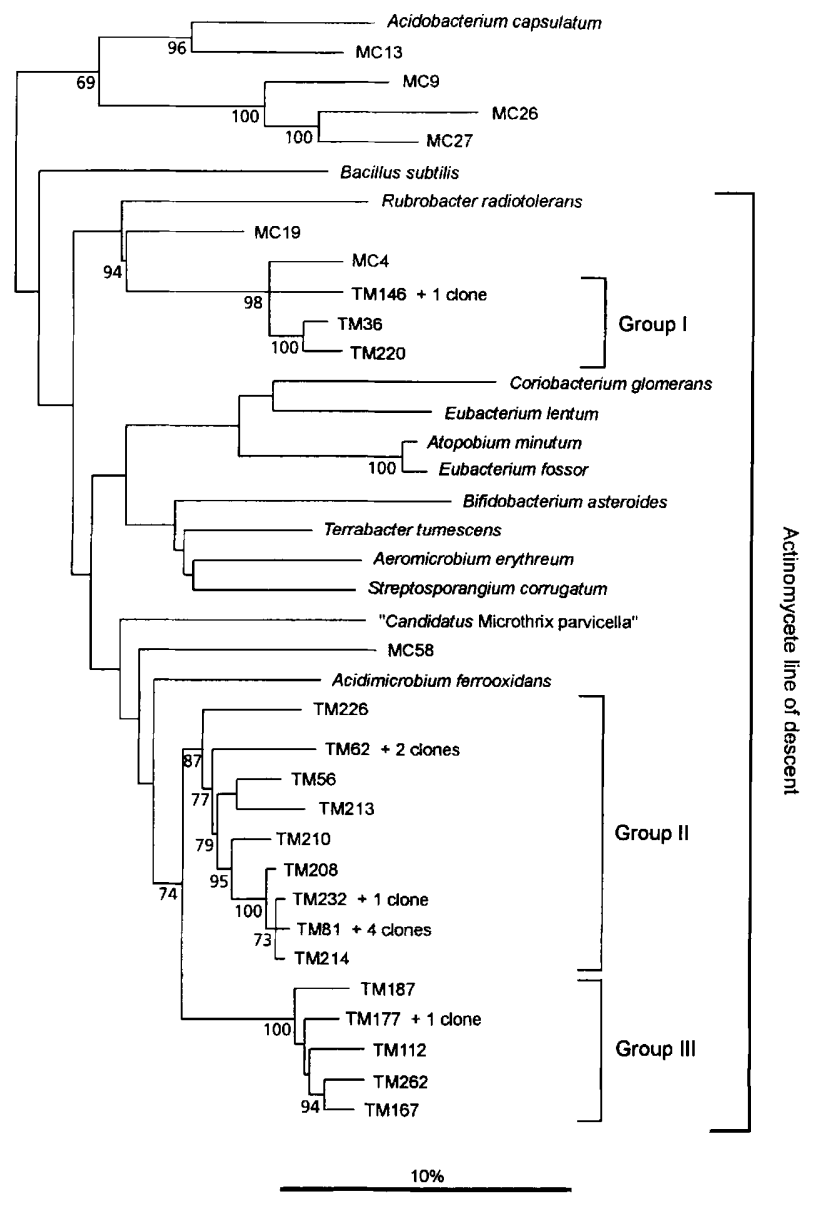

Fig. 2. Dendrogram based upon the distance method of DeSoete (1983) showing the phylogenetic position of TM groups I-III and related MC clone sequences within the actinomycete line of descent. Analysis is based upon the 5' 1000 nucleotides of the 165 rDNA sequences. Numbers indicate the percentages of occurrence in 100 bootstrapped trees. Only values above $65 \%$ are shown. The bar represents 10 nucleotide substitutions per 100 nucleotides. The number of partially sequenced TM clones with identical sequence (based on a comparison of about 500 nucleotides) is indicated next to the full sequence clone designation.

they are of different lengths and the stretches originate from different parts of the $16 \mathrm{~S}$ rDNA molecule. Comparison with the environmental $16 \mathrm{~S}$ rDNA clone sequences for which a common stretch of about 500 nucleotides is available indicated that three MC $16 \mathrm{~S}$ rDNA clone sequences from an Australian soil (Stackebrandt et al., 1993) exhibit a close (MC4) to moderate (MC19 and MC87) degree of relatedness to members of Group I (clone MC87 is not shown in Fig. 2, because its sequence comprises less than 500 nucleotides). MC clone clusters MC19 and MC87 appear to share a common origin with members of TM group I (bootstrap value of $94 \%$ ). Additional sequence information from a poster presentation (Saano et al., 1995) indicates that two short, identical 16S rDNA clone sequences obtained from a Finnish forest soil are about $92 \%$ similar to the Australian 16S rDNA clone sequences MC19 and MC87. 
Although the common sequence stretch comprises only 260 nucleotides, moderately high sequence similarity exists between two sequences from a paddy field (PAD, Maidak et al., 1994), three sequences from a soybean field in Japan (FIE, Ueda et al., 1995) and certain TM 16S rDNA clones, indicating that they are derived from phylogenetically closely related organisms. This is shown for the environmental clone sequence env. PAD57, which shares about $94 \cdot 4 \% 16 \mathrm{~S}$ rDNA similarity to clones TM210 and TM226 (group III), and for clone sequences env. PAD13 and the three sequences of the env. FIE2 cluster, showing $16 \mathrm{~S}$ rDNA sequence similarities between 88.4 and $90.9 \%$ to representatives of group I. In each case the phylogenetic analyses support the monophyletic origin of members of different environments of groups I and II.

Two further 16S rDNA sequences from a clone library generated from DNA isolated from a geothermally heated soil in New Zealand are monophyletically related to members of TM group II. These clones are NZ44 (93.0\% similarity) and NZ150 (89.2\% similarity). As the longest of the two clone sequences contains only 890 nucleotides (NZ150), they are not included in Fig. 2.

In the case of the marine clone sequences, only one of nine (BDA1-5) can be used in phylogenetic analysis as it comprises more than 600 nucleotides (Fuhrman et al. 1993). Its phylogenetic position is within group I of the TM clones. The remaining sequences from Bermuda and northeastern Pacific Sargasso Sea comprise only about 100 nucleotides of the $3^{\prime}$ half of the $16 \mathrm{~S}$ rDNA. This stretch of sequence is sufficient to link them to clone sequence $\mathrm{BDA} 1-5$ on the basis of similarity.

\section{DISCUSSION}

The outcome of the molecular investigation of a peat bog sample is the presence of a clone sequence cluster that has previously been described to be present in geographically widely separated soil environments, i.e. Australia, Finland, Japan, New Zealand, and in the Atlantic and Pacific oceans. The cultured phylogenetic relatives of the uncultured strains represented by the $16 \mathrm{~S}$ rDNA clone sequences are Acidomicrobium ferrooxidans, 'Candidatus Microthrix parvicella' and $R$ ubrobacter radiotolerans, which originate from New Mexico, Australia, and Japan, respectively. It is also interesting that these uncultured taxa originate from habitats of very different physicochemical composition, such as forested soil, paddy fields, soybean field, geothermally heated soil, and peat, while the cultured strains were isolated from a bioleach environment and from activated sludge. The properties of the environments from which these taxa and their cultured relatives originate have little in common with respect to the matrix composition. However, five of the environments - forested soils from Australia and Finland, peat, the geothermally heated soil from New Zealand, and the bioleach sample - are moderately to highly acidic habitats (Liesack \& Stackebrandt, 1992a; Rainey et al., 1993), while rice paddy fields, soybean field and sewage sludge tend to be in the neutral to alkaline $\mathrm{pH}$ range (Neue, 1993).

In this peat bog study, of the $25916 \mathrm{~S}$ rDNA clones investigated by dot-blot hybridization, 37 clones $(15 \%$ of the clones investigated) reacted with the Gram-positive probe. Of these, at least 26 (those for which $16 \mathrm{~S}$ rDNA sequences were determined) are monophyletically related to either the Acidimicrobium ferrooxidans or Rubrobacter radiotolerans lineages, representing at least $10 \%$ of the total $16 \mathrm{~S} \mathrm{rDNA}$ clones investigated. These values are comparable to the percentage of members of this uncultured taxon detected in the paddy field study (15 clones out of $64,23 \%$ ), Finnish forest soil ( 2 clones out of 11 , $18 \%$ ), the soybean field study ( 3 clones out of $20,15 \%$ ), and the marine environments (9 clones out of $61,15 \%$ ), while those from Australian soil were less abundant (8 out of $113,7 \%$ ). The percentage of clones belonging to this uncultured taxon detected in the geothermally heated soil sample from New Zealand was low, i.e. $1 \%$ ( 2 out of 165 clones). This habitat has a similar $\mathrm{pH}$ to the peat environment, but its extreme temperature conditions $\left(75^{\circ} \mathrm{C}\right)$ makes it less comparable to the other soil samples.

Previous concerns have been raised with respect to the influence of biases in the current methodologies available

Table 3. Experimental procedures used in the generation of 165 rDNA clone libraries from environmental samples from which TM cluster sequences have been recovered

\begin{tabular}{|c|c|c|c|c|c|c|c|}
\hline Habitat & $\begin{array}{l}\text { Cell lysis } \\
\text { procedure }\end{array}$ & PCR primers & $\begin{array}{c}\text { DNA } \\
\text { polymerase }\end{array}$ & Cloning system/method & $\begin{array}{l}\text { No. of clones } \\
\text { analysed or } \\
\text { reported }\end{array}$ & $\begin{array}{l}\text { Percentage of clones } \\
\text { investigated found } \\
\text { to be related to the } \\
\text { TM clone clusters I, } \\
\text { II and II* }\end{array}$ & Reference \\
\hline Peat bog (Getmany) & Enzymic & $27 f \quad 1385 r$ & Ultma & pCR-Script, blunt-end & 259 & 15 & This study \\
\hline Soybean field (Japan) & Freeze-thaw, enzymic & $1114 \mathrm{f}-1385 \mathrm{r}$ & Not indicated & p'T7 Blue T, A-T ligation & 20 & 15 & Ueda et al. (1995) \\
\hline Forest soil (Finland) & Not indicated & $66 \mathrm{f}-343 \mathrm{r}$ & Not indicated & pGEM- $T$, not indicated & 11 & 18 & Saano et al. (1995) \\
\hline Forest soil (Australia) & Bead beater, enzymic & $27 f-1224 r$ & Perkin-Elmer & M13, restriction site ligation & 113 & 7 & $\begin{array}{l}\text { Liesack \& } \\
\text { Stackebrandt (1992a) }\end{array}$ \\
\hline $\begin{array}{l}\text { Geothermal soil (New } \\
\text { Zealand) }\end{array}$ & Sonication, enzymic & $536 \mathrm{f}-1492 \mathrm{r}$ & Boehringer & $\begin{array}{l}\text { Blue Script, restriction site } \\
\text { ligation }\end{array}$ & 165 & 1 & Rainey et al. (1993) \\
\hline Paddy field soil & Not indicated & Not indicated & Not indicated & Not indicated & 64 & 23 & Maidak tt al. (1994) \\
\hline $\begin{array}{l}\text { Marine environment (Atlantic } \\
\text { and Pacific oceans) }\end{array}$ & Boiling in $1 \%$ SDS & $536 f-1385 r$ & Perkin-Elmer & M13, restriction site ligation & 61 & 15 & Fuhrman et al. (1993) \\
\hline
\end{tabular}

* Clusters as defined in Fig. 2. 
for molecular ecological studies and the inability of the molecular approach to estimate the degree of microbial diversity (Reysenbach et al., 1992; Farrelly et al., 1995; Kopzynski et al., 1994; Rainey et al., 1996). Although these biases undoubtedly influence the taxon composition of the clone libraries obtained, it is noteworthy that the uncultured taxa of the Acidimicrobium and Rubrobacter lines of descent were found in the different clone libraries even though significantly different experimental procedures were employed (Table 3 ).

The information in Table 3 regarding the primers used and their corresponding target sites raises the problem of the lack of comparability between uncultured taxa. In the case of the soybean and the Finnish soil studies, the regions sequenced are totally different, with no overlap available for phylogenetic analysis. It is impossible to compare the sequence information obtained from these two environments, and the affiliation of their sequences to a known taxon can only be evaluated by separate analysis against a reference sequence that covers both regions. As pointed out recently in the literature (Stackebrandt \& Rainey, 1995; Ueda et al., 1995), the region amplified by the primer pair should be comparable with the majority of reference sequences and uncultured taxon sequences currently available. In order to be able to carry out more precise phylogenetic analysis, especially the determination of the branching points of novel lineages, we recommend the amplification of the almost complete $16 \mathrm{~S} \mathrm{rDNA}$ primary structure.

Little can be said about the possible taxonomic structure of groups I, II and III. Any relationship at the species and genus level can be excluded for any member of the three taxa and the two cultured relatives. Considering the current taxonomic structure of the order Actinomycetales (Embley \& Stackebrandt, 1994), even a relationship at the family level seems unlikely. Although the 16S rDNA clone sequences of the uncultured organisms fall into three phylogenetic groups, showing detailed internal structure, it is unwise to speculate on their taxonomic rank. The fact that the $16 \mathrm{~S} \mathrm{rDNA}$ sequences of the three groups form phylogenetically coherent clusters does not imply that the organisms from which the sequences were derived will be phenotypically or physiologically similar. For example the phylogenetic depth of group II is as large as that found between the anaerobic rod-shaped bifidobacteria and the aerobic mycelium-forming streptosporangia (Fig. 2). In addition, as long as only a single or a few strains are described for Acidimicrobium ferrooxidans and $R$ ubrobacter radiotolerans, nothing can be said about the range of physiological properties of these taxa. The shallower phylogenetic structure of groups I and III could be indicative of a more coherent phenotype for its members. Having identified this group of organisms by phylogenetic analysis, the emphasis should now be on the detection, isolation and characterization of strains, with the aim of elucidating their function in the ecosystem.

\section{ACKNOWLEDGEMENTS}

We thank Friedrich von Wintzingerode for providing un published data.

\section{REFERENCES}

Blackall, L. L., Seviour, E. M., Cunningham, M. A., Seviour, R. J. \& Hugenholtz, P. (1994). 'Microthrix parvicella' is a novel, deep branching member of the Actinomyces subphylum. Syst Appl Microbiol 17, 513-518.

Blackall, L. L., Stratton, H., Bradford, D., Del Dot, T., Sjörup, C., Seviour, E. M. \& Seviour, R. J. (1996). 'Candidatus Microthrix parvicella', a filamentous bacterium from activated sludge sewage treatment plants. Int J Syst Bacteriol 46, 344-346.

Brierley, J. A. (1978). Thermophilic iron-oxidizing bacteria found in copper leaching dumps. Appl Environ Microbiol 36, 523-525.

Cabot, E. L. \& Beckenbach, A. T. (1989). Simultaneous editing of multiple nucleic acid and protein sequences with ESEE. Comput Appl Biosci 5, 233-234.

Clark, D. A. \& Norris, P. R. (1996). Acidimicrobium ferrooxidans gen. nov., sp. nov.: mixed culture ferrous iron oxidation with Sulfobacillus species. Microbiology 142, 785-790.

DeSoete, G. (1983). A least squares algorithm for fitting additive trees to proximity data. Psychometriked 48, 621626.

Embley, T. M. \& Stackebrandt, E. (1994). 'The molecular phylogeny and systematics of the Actinomycetes. Annu Rev Microbiol 48, 257-289.

Farrelly, V., Rainey, F. A. \& Stackebrandt, E. (1995). Effect of genome size and rrngene copy number on PCR amplification of $16 \mathrm{~S}$ rRNA genes from a mixture of bacterial species. Appl Environ Microbiol 61, 2798-2801.

Felsenstein, J. (1993). PHYLIP (Phylogeny Inference Package), version 3.5.1. Seattle: Department of Genetics, University of Washington.

Fuhrman, J. A., McCallum, K. \& Davis, A. A. (1993). Phylogenetic diversity of subsurface marine microbial communities from the Atlantic and Pacific oceans. Appl Environ Microbiol 59, 1294-1302.

Hiraishi, A., Kishimoto, N., Kosako, Y., Wakao, N. \& Tano, T. (1995). Phylogenetic position of the menaquinone-containing acidophilic chemo-organotroph Acidobacterium capsulatum. FEMS Microbiol Lett 132, 91-94.

Holben, W. E., Jansson, J. K., Chelm, B. K. \& Tiedje, J. M. (1988). DNA probe method for the detection of specific microorganisms in the soil bacterial community. Appl Environ Microbial 54, 703-711.

Jukes, T. H. \& Cantor, C. R. (1969). Evolution of protein molecules. In Mammalian Protein Metabolism, pp. 21-132. Edited by H. N. Munro. New York: Academic Press.

Kishimoto, N., Kosako, Y. \& Tano, T. (1991). Acidobacterium capsulatum gen. nov., spec. nov.: an acidiphilic chemoorganotrophic bacterium containing menaquinones from acidic mineral environment. Curr Microbiol 22, 1-7.

Kopzynski, E. D., Bateson, M. M. \& Ward, D. M. (1994). Recognition of chimeric small-subunit ribosomal DNAs composed of genes from uncultivated microorganisms. Appl Environ Microbiol 60, 746-748.

Lane, D. J. (1991). 16S/23S rRNA sequencing. In Nucleic Acid Techniques in Bacterial Systematics, pp. 115-175. Edited by E. Stackebrandt \& M. Goodfellow. Chichester; Wiley.

Lane, D. J., Harrison, A. P., Jr, Stahl, D., Pace, B., Givannoni, S. J., Olsen, G. J. \& Pace, N. R. (1992). Evolutionary relationships among sulfur- and iron-oxidising eubacteria. J Bacteriol 174, 269-278.

Liesack, W. \& Stackebrandt, E. (1992a). Occurrence of novel groups of the domain Bacteria as revealed by analysis of genetic material isolated from an Australian terrestrial environment. $J$ Bacteriol 174, 5072-5078.

Liesack, W. \& Stackebrandt, E. (1992b). Unculturable microbes 
detected by molecular sequences and probes. Biodivers Conserv 1, 250-262.

Maidak, B. L., Larsen, N., McCaughey, M. J., Overbeck, R., Olsen, G. J., Fogel, K., Blandy, J. \& Woese, C. R. (1994). The Ribosomal Database Project. Nucleic Acids Res 22, 3483-3487.

Neue, H.-U. (1993). Methane emission from rice fields. Bio Science 43, 466-473.

Ogram, A., Sayler, G. S. \& Barkay, T. (1987). The extraction and purification of microbial DNA from sediments. J Microbiol Methods 7, 57-66.

Rainey, F. A., Ward, N. L. \& Stackebrandt, E. (1993). Molecular ecology study of a New Zealand acidothermal soil. In Thermophiles '93, Hamilton, New Zealand, Abstract A7. Hamilton: University of Waikato.

Rainey, F. A., Ward-Rainey, N. L., Janssen, P. H., Hippe, H. \& Stackebrandt, E. (1996). Clostridium paradoxum DSM $7308^{\mathrm{T}}$ contains multiple $16 \mathrm{~S}$ rRNA genes with heterogeneous intervening sequences. Microbiology 142, 2087-2095.

Reysenbach, A., Giver, L. J., Wickham, G. S. \& Pace, N. R. (1992). Differential amplification of $16 \mathrm{~S}$ rRNA genes by the polymerase chain reaction. Appl Environ Microbiol 58, 3417-3418.

Saano, A., Lindström, K. \& Van Elsas, J. D. (1995). Eubacterial diversity in Finnish forest soil. In 7 th International Symposium on
Microbial Ecology, Santos, Brazil, Abstract P1-3.9. Santos: Brazilian Society for Microbiology.

Stackebrandt, E. \& Liesack, W. (1993). Nucleic acids and classification. In Handbook of New Bacterial Systematics, pp. 151-194. Edited by M. Goodfellow \& A. O'Donnell. New York: Academic Press.

Stackebrandt, E. \& Rainey, F. A. (1995). Partial and complete $16 \mathrm{~S}$ rDNA sequences, their use in generation of $16 \mathrm{~S}$ rDNA phylogenetic trees and their implications in molecular ecological studies. In Molecular Microbial Ecology Manual, pp. 3.1.1: 1-17. Edited by A. D. L. Akkermans, J. D. van Elsas \& F. J. de Bruijn. Dordrecht: Kluwer.

Stackebrandt, E., Liesack, W. \& Goebel, B. M. (1993). Bacterial diversity in a soil sample from a subtropical Australian environment as determined by $16 \mathrm{~S}$ rDNA analysis. F ASEB 7, 232-236.

Ueda, T., Suga, Y. \& Matsuguchi, T. (1995). Molecular phylogenetic analysis of a soil microbial community in a soybean field. Eur I Soil Sci 46, 415-421.

von Wintzingerode, F. (1994). Phylogenetische und chemotaxonomische Hinweise auf die Anwesenbeit neuer Bakterienarten in einer Torflagerstätte in Ost-Niedersachsen. Diploma thesis, Braunschweig Technical University, Germany.

Received 6 March 1996; revised 12 June 1996; accepted 24 June 1996. 